\title{
Hubungan Konsep Diri dan Self Control dengan Kebermaknaan Hidup
}

\section{(Releationship Between Self Concept And Self Control With Life Meaning)}

\author{
Muhammad Ghozali Ma'ruf \\ Fakultas Psikologi, Universitas 17 Agustus 1945 Surabaya \\ mg.makruf@gmail.com
}

\begin{abstract}
Abstrak
Penelitian ini mempunyai tujuan untuk mengetahui hubungan antara konsep diri dan self control dengan kebermaknaan hidup. Variabel penelitian ini meliputi variabel bebas konsep diri (variabel X1) dan self control (variabel X2) dan variabel tergantung kebermaknaan hidup (variabel Y). Metode yang digunakan dalam pengambilan sampel dalam penelitian ini adalah sampling purposive yaitu dengan menentukan kriteria tertentu dalam pemilihan subjek remaja di Madrasah Aliyah Mathali'ul Anwar di Simo-Lamongan yang berusia 14-19 tahun. Metode yang digunakan untuk mengumpulkan data tentang konsep diri, self control dan kebermaknaan hidup menggunakan angket. Hasil analisis data menggunakan anareg mendapat hasil $\mathrm{F}$ Regresi $=73.413$ dengan signifikasi $\mathrm{p}=0.000(\mathrm{p}<0.05)$ menunjukkan bahwa konsep diri dan self control sangat signifikan berkorelasi dengan kebermaknaan hidup. Hasil analisis parsial pada variabel konsep diri dengan kebermaknaan hidup menunjukkan nilai $\mathrm{t}=1.131$ pada $\mathrm{p}=0.316$ hal ini berarti bahwa terdapat hubungan negatif antara konsep diri dengan kebermaknaan hidup. Implikasi penelitian ini dapat menjadi acuan tentang bagaimana manusia lebih bermakna hidupnya.
\end{abstract}

Kata kunci: Konsep diri, Self Control dan Kebermaknaan Hidup

\begin{abstract}
The purpose of this study was to determine the relationship between self concept and self-control with life meaning. The variabel of this study include self concept independent variable (variable X1) and selfcontrol (variable X2) and dependent variable of life meaning (variable Y). The method used for sampling in this study is purposive sampling that is by ditermining certain criteria in the selection of subjects is adolescents in islamic hight school Mathali'ul Anwar at Simo-Lamongan aged 14-19 years. The methods used to collect data on self concept, self control and life meaning use questionnaires. The result of data analysis using Anareg got the result of $F$ Regression $=73.413$ with significance $p=0.000(p<0.05)$ showed that self concept and self control were significantly correlated with life meaning. The result of partial analysis on self concept with dependence of life meaning show $t$ value 1.131 at $p=0.316$ this means that there is negatif relation between self concept variable with life meaning. The findings to be a reference to make people meaningfullnes at his life.
\end{abstract}

Keywords: Self Concept, Self-Control, Life Meaning

\section{Pendahuluan}

Terdapat beberapa fakta yang terjadi pada kalangan siswa. Fakta yang menyita perhatian tersebut di antaranya adalah kasus penganiyaan. Misalnya, penganiayaan oleh siswa terhadap gurunya yang terjadi di Sampang Madura, Ahmad Budi Cahyono yang tewas dianiayan oleh muridnya sendiri. Guru kesenian yang berstatus sebagai guru honorer tersebut telah berpulang karena muridnya sendiri. Penganiayaan tersebut điawali ketika tersangka tidak menerima karena ditegur oleh gurunya sendiri (dalam http://www.bbcnews.com, diakses 05, Maret 2018). Selain itu, seorang guru dianiaya oleh 
muridnya sendiri menggunakan kursi. Kasus ini menimpa seorang guru yang bernama Bu Rahayu. Kejadian yang terjadi pada tahun 2017 tersebut dilakukan oleh seorang siswa di SMA Negeri I Kubu Raya Kalimantan Barat. Bahkan, kasus penganiayaan murid juga terjadi di Makasar, SMKN II Makasar. Penganiayaan tersebut menimpa seorang guru yang bernama Dasrul (dalam http://www. tribunnews.com, diakses 05, Maret 2018).

Kasus yang lain adalah aksi tawuran oleh siswa, baik antara kelompok di dalam sekolah atau pun luar sekolah. Dalam setahun, terdapat 82 pelajar tewas akibat tawuran (dalam http://www.liputan6.com, diakses 05, Maret 2018). Pada 2016, kasus tawuran yang terjadi di Jogjakarta mengalami peningkatan yaitu menjadi 43 kasus (dalam http://www.DetikNews.com, diakses 05 Maret 2018). hal ini menjelaskan peningkatan kasus tersebut.

Kasus narkoba juga menjadi hal yang memprihatinkan. Pasalanya, menurut Badan Narkotika Nasional (BNN) sepanjang tahun 2017 mengungkap 46.537 kasus narkoba. Bahkan, ditemukannya juga jenis narkoba baru menjadi 68 jenis ((dalam http://www.idntimes.com, diakses 05, Maret 2018).). 27\% pengguna narkoba adalah pelajar dan mahasiswa. Data tersebut didapat dari penelitian Puslitkes Universitas Indonesia (UI) dan badan Narkotika Nasional BNN pada tahun 2016 (dalam http://www.republika.co.id, diakses 05, Maret 2018).

Hal demikian menunjukkan bahwa siswa mengalami kehidupan yang tak bermakna. Kebermaknaan hidup adalah penghayatan individu sejauh mana hidupnya berguna dan berarti (Setyarini \& Atamimi, 2011). Bastaman menyebutkan (Bastaman, 2004), bahwa makna hidup adalah sesuatu yang dianggap penting dan berguna, sehingga layak dijadikan sebagai tujuan hidup. Apabila hal tersebut tercapai, maka individu akan merasa bermakna (Bastaman, 2004).

Betapa pentingnya kebermaknaan hidup bagi siswa. Sehingga, dapat mengarahkan perilakunya di dalam kehidupan sehari-hari. Namun tidaklah mudah, untuk menyelamatkan generasi bangsa. Kekerasan yang terjadi akhir-akhir ini bila dibiarkan maka akan semakin bertambah, dan generasi masa depan ini akan terancam rusak moralnya.

Remaja yang tidak berhasil menemukan makna hidupnya akan mengalami penghayatan hidup tanpa makna (meaningless) yang dicirikan sebagai remaja yang kehilangan arah, kehilangan minat, bosan, merasa hidupnya tak berarti dan apatis. Hal yang demikian bila dibiarkan secara terus menerus akan menjelma dalam konpensasi yang berlebihan seperti berusaha selalu mencari kenikmatan dan kesenangan, seks, kehilangan arah. Makna hidupnya diperlukan bagi para remaja agar tidak terjerumus oleh pengaruh dari lingkungan pergaulannya yang salah (Bastaman, 2004). Selain itu, remaja tersebut akan mengalami kekecewaan dan kehampaan yang dapat menimbulkan gangguan perasaan dan menghambat penyesuaian dirinya dan prestasi belajarnya (Kurniawan \& Widyana, 2014).

Crumbaugh dan Maholick (Koeswara, 1992) mengatakan bahwa kebermaknaan hidup adalah seberapa tinggi individu mengalami hidupnya bermakna. Menurut Frankl makna hidup seseorang tidak dapat dipisahkan dari tujuan hidupnya, yaitu hal-hal yang perlu dicapai dan dipenuhi (dalam Bastaman, 2004). Frankl (dalam Bastaman, 2004) menyatakan bahwa makna hidup seseorang bersifat objektif, menuntut, dan mutlak. Individu yang memiliki makna dalam hidupnya akan menjalani kehidupan sehari-hari dengan gairah dan semangat hidup serta jauh dari perasaan hampa. Individu dapat menemukan makna hidupnya di dalam kehidupannya itu sendiri, kalaupun suatu saat ia mengalami kondisi yang tidak menyenangkan, maka ia akan menghadapinya dengan tabah.

Hasil penelitian Siska Marliana Lubis dan Sri Maslihah (2012) mengenai analisis sumbersumber kebermaknaan hidup menyebutkan terdapat tiga nilai yang menjadi sumber kebermaknaan hidup. Berdasarkan uraian penelitian ini, mempertegas bahwa makna hidup didapatkan dari tiga nilai: nilai kreatif, nilai penghayatan dan nilai bersikap. Dalam hal ini, nilai bersikap dan penghayatan lebih dominan mempengaruhi sejauh mana penghayatan para narapidana terhadap hidupnya.

Pada perkembangannya, menurut Monks (2009) remaja dibagi menjadi tiga tahapan: remaja awal (12-15 tahun), remaja madya (15-18 tahun) dan remaja akhir (18-21 tahun). Pada tahapan remaja awal, ia belum mampu menginternalisasikan nilai-nilai yang ada pada dirinya dan masyarakatnya. Hal itu disebabkan karena pada masa ini remaja masih memiliki emosi yang labil dan memperhatikan citra diri. Sehingga, pencarian akan suatu yang dianggap penting dan bernilai baru dialami pada masa remaja madya antara umur 15 tahun hingga 18 tahun. Pada masa ini, remaja mencari dan menemukan standar nilai yang ada. Sedangkan pada tahapan remaja akhir remaja telah mengembangkan nilai dan makna hidupnya. 
Konsep diri dan Self control memiliki peran terhadap kebermaknaan hidup siswa. Menurut Anggriyani, kebermaknaan hidup berkaitan dengan kualitas insani; pengembangan diri (dalam Mayaza dan Supradewi, 2011).

Menurut Suyanti, konsep diri merupakan kepercayaan, sikap, pengetahuan dan pemikiran individu tentang pribadinya (Suyanti, 2011). Siswa dengan konsep diri yang positif dicirikan sebagai siswa memiliki penilaian yang positif terhadap segala aspek dirinya sendiri. Yaitu, menyangkut aspek fisik, moral, sosial dan psikologis. Siswa dengan konsep diri yang positif tersebut akan mampu meraih kehidupan yang bermakna. Ia juga bisa menempatkan antara diri sebagai kenyataan dan sebagai harapan. Penilaian yang positif terhadap diri sendiri akan mengarahkan individu kepada apa yang penting menurut dirinya. Ketika hal tersersebut tercapai, maka ia akan semakin merasa bermakna hidupnya.

Individu dengan konsep diri yang baik memiliki sikap dan pandangan yang baik terhadap dirinya sendiri, kemampuan dan segala kelebihan dan kekurangan dirinya. Ketika ia menghadapi suatu masalah di dalam lingkungan sekolahnya dan keluarganya ia bersikap bijaksana. Pada yang demikian sebenarnya ia telah menerapkan nilai-nilai penghayatan (experiential values) sebagai salah satu nilai kehidupan yang dapat menjadikan individu meraih kebermaknaan hidupnya.

Selain itu, individu dengan konsep diri yang baik melaksanakan perannya dalam keluarga dan lingkungannya dengan sebaik-baiknya dan penuh tanggung jawab. Hal ini menandakan bahwa individu melaksanakan nilai-nilai kreatif yang merupakan nilai yang dapat menjadikan individu merasakan kebermaknaan di dalam hidupnya (Bastaman, 2004).

Gufron dan Risnawita (dalam Haryani \& Herwanto, 2015) mendefinisikan self control sebagai kemampuan individu di dalam mengendalikan emosi serta dorongan-dorongan dari dalam dirinya. Pengendalian ini menyangkut tanggung jawab atau komitmen di dalam bekerja (creative value). Menurut Bastaman, nilai-nilai tersebut tercermin dalam kegiatan bekerja, berkarya, melaksanakan kewajiban yang dilakukan dengan penuh tanggung jawab dan komitmen (Bastaman, 2004). Dengan totalitas tersebut, individu akan merasakan hidupnya bermakna.

Pada penelitian sebelumnya, sebagaimana yang diteliti oleh Kharisma Nail Mazaya dan Ratna Supradewi (2011). Penelitian yang dilakukannya untuk menguji adakah hubungan antara variabel konsep diri dan variabel kebermaknaan hidup. Hasil penelitian menunjukkan ada hubungan positif antara kedua variabel tersebut. Dengan demikian terdapat perbedaan dengan penelitian yang akan dilaksanakan oleh peneliti. Dalam hal ini, peneliti menggunakan tiga variabel, yaitu ditambah dengan self control sebagai variabel independent (X) dengan tetap menjadikan kebermaknaan hidup sebagai variabel dependent (Y).

\section{Kebermaknaan Hidup}

Frankl (dalam Bastaman, 2004) mengatakan bahwa makna hidup adalah sesuatu yang dirasa dianggap bernilai, penting dan didambakan bagi individu sehingga ia layak dijadikan sebagai tujuan hidupnya. Crumbaugh dan Maholick sebagaimana dikutip oleh Lubis mendefinisikan makna hidup sebagai kamampuan individu di dalam penentuan pola nilai-nilai dan tujuan yang terintegrasi ke dalam kehidupannya (Lubis \& Maslihah, 2012). Maka, makna hidup merupakan suatu hal-nilai-nilai atau pun tujuan-tujuan-yang dianggap penting dan didambakan sehingga layak untuk dijadikan sebagai tujuan hidupnya.

Kebermaknaan hidup menurut Crumbaugh dan Makholick adalah penghayatan individu mengenai apa yang dianggapnya bernilai, diyakininya sebagai suatu kebenaran dan memberikan nilai khusus serta dapat dijadikan sebagai tujuan hidupnya yang didasarkan pada komponen makna hidup, kepuasan hidup, kebebasan berkehendak, sikap terhadap kematian, pikiran bunuh diri dan kepantasan hidup (dalam Koeswara, 1992). Hal serupa juga diungkap oleh Mazaya dan Supradewi (2011), kebermaknaan hidup merupakan kualitas insani atau pengembangan diri. Perbedaan pendapat dari beberapa definisi sebenarnya adalah perbedaan dalam sudut pandang, namun nyatanya kesemuanya sama bahwa di dalam kebermaknaan hidup seseorang diharapkan bertindak mengenai apa yang dianggapnya penting dan memberikan nilai khusus dengan didasarkan pada semangat totalitas untuk mencapainya. Frankl (dalam Koeswara, 1992) makna hidup bersifat menantang, karena itulah dibutuhkan suatu usaha yang optimal dan penuh kesungguhan yang muncul dari kedalaman dan pusat kepribadian individu.

Bastaman (2004) mengatakan bahwa kebermaknaan hidup adalah kualitas penghayatan individu terhadap seberapa besar dirinya mampu mengembangkan potensi-potensi dan kapasitas 
dirinya, seberapa jauh ia berhasil mencapai tujuan-tujuan hidupnya dan upaya memberikan makna pada kehidupannya. Menurut Bastaman (2004) terdapat tiga dimensi kebermaknaan hidup: 1) Makna Hidup, 2) Kebebasan Berkehendak, dan 3) Kepuasan Hidup.

\section{Konsep Diri}

Brooks (dalam Rakhmat, 2012) mengatakan bahwa konsep diri adalah persepsi individu terhadap dirinya yang bersifat fisik, sosial, psikologis sebagai hasil dari interaksi dengan orang lain dan dari pengalaman pribadinya. Lebih lanjut, Rakhmat (2012) mengemukakan bahwa konsep diri bukan saja gambaran deskriptif mengenai diri sendiri, tetapi juga penilaian terhadap diri tersebut. Yaitu, mencangkup apa yang dipikirkan dan dirasakan tentang diri sendiri, dan pandangan terhadap diri sendiri, Thalib (dalam Lukman, 2000). Beberapa pendapat di atas menunjukkan bahwa konsep diri merupakan anggapan, penilaian atau pun persepsi individu terhadap dirinya sendiri yang meliputi aspek fisik, sosial dan psikologis sebagai hasil dari interaksi dirinya dengan orang lain atau pun pengalaman kehidupan dirinya.

Meece (dalam Suryanti, 2011) menambahkan bahwa konsep diri tidak semata-mata hasil penilaian individu terhadap dirinya sendiri, tetapi harus dilaksanakan dengan penuh integritas yang melibatkan kepercayaan individu, pemikiran, sikap dan pengetahuan yang didapatkan dari pengalaman pribadi dan interaksi sosialnya.

Konsep diri menurut Fitts (1965) memiliki dimensi-dimensi sebagai berikut ini: 1) Diri fisik, yaitu menggambarkan bagaimana seseorang menilai kondisi kesehatan, badan dan penampilan fisiknya. 2) Diri Etik dan Moral, yaitu menggambarkan bagaimana individu menilai mengenai nilai-nilai moral yang dianutnya: sifat-sifat baik dan jelek serta hubungannya dengan tuhannya. 3) Diri Sosial, yaitu menandakan sejauh mana seseorang merasakan bahwa dirinya mampu serta berharga dalam interaksi sosialnya bersama orang lain. 4) Diri pribadi, yaitu menggambarkan penilaian individu terhadap kemampuan dirinya sendiri dan dengan interaksi sosialnya, 5) Diri keluarga adalah dimensi yang menggambarkan perasaan berarti dan berharga dalam kepastiannya sebagai anggota di dalam sebuah keluarga.

\section{Self Control}

Hurlock (dalam Khairunnisa', 2013) mengatakan bahwa self control merupakan bagaimana individu dapat mengedalikan emosinya dan dorongan-dorongan yang ada di dalam dirinya. Goldfried dan Merbaum (dalam Aviyah dan Farid, 2014) mempertajam pengertian tersebut dengan mengatakan bahwa self control merupakan aktivitas individu dalam mengendalikan perilaku, kemampuan untuk menyusun, membimbing, mengatur dan mengarahkan perilaku yang dapat memberikan suatu hasil konsekuensi yang positif. Pendapat-pendapat di atas mengarahkan suatu kesimpulan bahwa self control merupakan kemampuan individu dalam mengendalikan dan mengarahkan pemikiran, emosi dan perilaku guna menghasilkan suatu konsekuensi yang positif.

Self control memiliki beberapa dimensi, menurut Averill terdapat tiga dimensi (dalam Wulaningsih dan Hartini, 2015), yaitu: 1) Kemampuan mengontrol perilaku (behavioral control), 2) Kontrol kognitif (cognitive control), 3) Kemampuan mengontrol keputusan (decisional control).

Adapun hubungan antar variabel dapat dijelaskan sebagai berikut. Menurut Rakhmat (2012) menyatakan mengenai konsep diri yang tak sesempit hanya bagaimana individu menilai dirinya, tetapi juga bagaimana ia memikirkan dan merasakan akan keberadaan dirinya sendiri. Pelaksanaan nilainilai yang menghantarkan kepada kebermaknaan hidup berkaitan dengan konsep diri.

Konsep diri yang positif berpengaruh terhadap perilakunya, yaitu membawa kepada perilaku positif. Sebaliknya, konsep diri yang negatif atau kurang juga membawa pengaruh kepada perilaku yang negatif. Individu dengan konsep diri yang positif mampu memahami dan menerima sejumlah kenyataan akan dirinya sendiri dan tidak menganggapnya sebagai sebuah ancaman nyata. Hal ini tentu merupakan faktor pengaruh yang membawa implementasi pada nilai-nilai penghayatan. Nilai ini digambarkan sebagai sikap diri menyerahkan diri kepada kehidupan. Individu yang bertindak positif sesuai konsep dirinya akan merasakan pertemuan dengan kebenaran, kebijaksanaan dan kebajikan. Penghayatan dan keyakinan yang demikian menyebabkan individu merasakan kebermaknaan dalam hidupnya.

Selain itu, konsep diri yang negatif ikut menghambat dari kebermaknaan hidup seseorang. Individu dengan konsep diri yang negatif cenderung menghindar dari komunikasi dengan orang lain, peka terhadap kritikan, pesimistis mengenai keadaan, menunjukkan perilaku yang negatif pula. Tentu implementasi dari nilai-nilai penghayatan maupun nilai-nilai kreativitas terhambat. 
Hurlock mengungkapkan bahwa self control berkaitan dengan bagaimana individu mengendalikan emosi serta dorongan-dorongan dalam dirinya (Khairunnisa', 2013). Sedangkan menurut Goldfried \& Merbaum sebagai suatu aktivitas pengendalian tingkah laku, kemampuan untuk menyusun, membimbing, mengatur dan mengarahkan bentuk perilaku yang dapat membawa individu ke arah konsekuensi positif (Aviyah \& Farid, 2014). Averill mendefinisikan bahwasannya self control sebagai sebagai variabel psikologis yang mencakup kemampuan individu untuk memodivikasi perilaku, mengelola informasi, dan memilih tindakan sesuai dengan hal yang diyakini (Kusumadewi, dkk., 2012). Maka dapatlah disimpulkan jika self control adalah suatu kemampuan individu di dalam mengendalikan tingkah laku, mengatur dan membimbing serta mengerahkannya ke arah konsekuensi positif.

Berkat status makna hidup yang objektif itulah mengapa ia memiliki sifat menantang, dan menuntut individu untuk mencapainya. Bila tidak demikian, maka hanya sekedar ungkapan nalurinaluri saja yang tidak menuntut individu mencapainya. Selain itu, makna hidup juga disebut-sebut sebagai nilai-nilai situasional. Dalam hal ini makna hidup yang dicapai seseorang tidak bersifat abadi dan selamnya, melainkan bersifat sementara sesuai kawasan kondisinya yang sedang dihadapinya. Karena itulah makna hidup yang menantang individu bersifat unik dan spesifik dari suatu keadaan tertentu (Koeswara, 1992). Di dalam upaya mencapai makna hidup yang menantang dan menuntut tersebut diperlukanlah suatu sikap totalitas daripada pelaksanaan upaya realisasi tugas hidup individu yang tercermin di dalam nilai kreatif.

Upaya pencapaian makna hidup dapat direalisasikan dengan nilai-nilai kreatif. Nilai-nilai ini tercermin dalam tugas hidup, maka secara umum implementasinya berhubungan dengan aktivitas kerja yang diupayakan oleh individu. Pada kondisi yang demikian individu menampilkan keunikan keseluruhan dari dirinya. Namun yang perlu dipahami bahwa makna hidup terpisah daripada aktivitas kerja individu, karenanya setiap aktivitas tidak selalu dipastikan dapat membawa kepada peluang pemenuhan makna hidup. Oleh sebab makna hidup yang menantang sebagaimana dijelaskan di atas, maka diperlukan kesungguhan dan totalitas pelaksanaan tugas hidup individu tersebut.

Frankl (2003) menyebutkan bahwa makna hidup tidak bisa dicapai hanya dengan proses akal dan intelektual. Pencapaian makna hidup diusahakan dengan suatu tindakan yang sungguh-sungguh yang muncul dari pusat kepribadiannya, dan karena itu usahanya berasal dari keberadaan totalnya. self control merupakan kemampuan individu di dalam mengendalikan perilakunya dalam mengupayakan hasil yang positif ikut memberikan pengaruh kepada pencapaian individu terhadap kebermaknaan hidup. Kontrol kognitif, perilaku dan keputusan berkaitan dengan usaha individu dalam mengupayakan tugas hidupnya sebagai implementasi totalitas dari kedalaman kepribadiannya. Sehingga denga itulah individu merasakan kebermaknaan di dalam hidupnya.

Kemampuan mengontrol perilaku adalah kemampuan di dalam mengontrol suatu stimulus dan respon sehingga tidak terjadi ledakan emosi dan frustasi yang meliputi kemampuan mengatur pelaksanaan dan memodifikasi stimulus. Selain itu, di dalam menghadapi tekanan psikologis dalam upaya pelaksanakaan impelementasi tugas individu diperlukan kemampuan mengontrol kognitif, yaitu kemampuan menilai dan menginterpretasikan suatu kejadian dalam kerangka kognitif.

Kemampuan mengontrol keputusan juga diperlukan dalam implementasi nilai-nilai kreatif. Pada kemampuan ini individu memilih hasil dari tindakannya berdasarkan apa yang diyakininya. Sehingga, dalam yang demikian memungkinkan individu dengan bebas dengan adanya kesempatan mencapai apa hasil daripada tugas hidup individu yang disetujuinya. Ketiga komponen self control di atas pada akhirnya mempengaruhi daripada implementasi nilai-nilai kreatif yang membawa kepada kebermaknaan hidup pada individu. Berlandaskan hal tersebut peneliti ingin mengetahui adakah hubungan antara konsep diri dan self control dengan kebermaknaan hidup. Hipotesis dari penelitian ini, yaitu:

1. Ada hubungan antara konsep diri dan self control dengan kebermaknaan hidup pada siswa.

2. Ada hubungan antara konsep diri dengan kebermaknaan hidup pada siswa.

3. Ada hubungan antara self control dengan kebermaknaan hidup pada siswa.

\section{Metode Penelitian}

Penelitian ini menggunakan pendekatan kuantitatif. Dalam penelitian ini, peneliti mengidentifikasi tiga variabel yang nantinya akan dicari hubungannya. Adapun variabel tersebut adalah: Independent Variabel atau variabel bebas (x1) adalah konsep diri, yaitu bagaimana individu 
menggambarkan dan meyakini keadaan dirinya sendiri secara internal dan eksternal yang didasarkan pada pengalaman pribadinya atau interaksinya dengan orang lain, (x2) adalah self control, yaitu aktivitas pengendalian perilaku, emosi dan dorongan-dorongan dengan melibatkan kemampuan memodifikasi perilaku, mengolah informasi yang dimiliki dan memilih tindakan yang sesuai demi mencapai suatu konsekuensi yang positif. Sedangkan Dependent Variabel atau variabel terikat (y) adalah dan kebermaknaan hidup, merupakan tingkat penghayatan kehidupan seseorang terhadap tujuan hidupnya, apa yang dianggapnya penting dan berguna sehingga menjadikan hidupnya bermakna.

Populasi dalam penelitian ini adalah para siswa yang menempuh pendidikan di Madrasah Aliyah (MA) Mathali'ul Anwar Simo di Kabupaten Lamongan. Populasi tersebut berjumlah sebanyak 1.500 siswa. Berdasarkan jumlah populasi yang sedemikian, maka peneliti menggunakan sampel. Sampel dapat dipahami sebagai bagian daripada populasi dan mewakilinya terkait segala gejala yang ada. Jumlah sampel tidak dapat ditentukan secara pasti. Namun, jumlah sampel yang melebihi dari 60 orang sudah dianggap cukup banyak (Azwar, 2013). Adapun teknik penentuan sampel didasarkan pada suatu kriteria tertentu, yaitu siswa yang menempuh pendidikan di Madrasah Aliyah (MA) Mathali'ul Anwar Simo Kabupaten Lamongan dengan rentan usia 13-19 tahun. Berdasarkan kriteria tersebut didapatkanlah sampel yang berjumlah 120 siswa.

Metode pengumpulan data yang dipakai dalam penelitian ini adalah metode skala, skala konsep diri, skala self control dan skala kebermaknaan hidup. Metode skala yang digunakan peneliti adalah skala likert.

Skala konsep diri, self controli dan kebermaknaan hidup disusun untuk dapat mengukur atribut psikologi dalam penelitian ini. Skala-skala tersebut disusun berdasarkan dimensi-dimensi dan indikator-indikator dari suatu variabel penelitian yaitu variabel konsep diri, variabel self control dan variabel kebermaknaan hidup. Skala kebermaknaan hidup disusun dengan menggunakan dimensidimensi kebermaknaan hidup Bastaman berdasarkan teori Viktor Frankl (2004), yaitu: 1) Makna Hidup dalah suatu hal yang dianggap penting, benar dan didambakan serta memberikan nilai tersendiri bagi individu. Bila makna tersebut dapat dicapai dan terpenuhi, maka individu akan merasakan hidupnya sebagai suatu yang berharga dan berarti. Makna hidup mengandung tujuan hidup yang menantang individu untuk menggapainya, 2) Kebebasan Berkehendak (Freedom of will) adalah kebebasan yang dimiliki individu dalam upaya menentukan sikapnya terhadap kehidupannya. Yaitu, apa yang dianggapnya sebagai hal yang penting atau tidak bagi dirinya. Meskipun demikian, kebebasan ini tetap bersifat tidak mutkhlak, di dalamnya terkandung tanggungjawab yang tak bisa dikesampingkan, dan 3) Kepuasan hidup merupakan penilaian individu terhadap hidupnya; sejauh mana ia dapat menikmatinya dan merasakan kepuasaan terhadap aktivitas-aktivitas yang dilakukannya di dalam kehidupannya. Skala Kebermaknaan Hidup berjumlah 49 aitem uji coba dan dihasilkan sebanyak 34 aitem valid yang digunakan dalam penelitian ini. Kemudian skala konsep diri disusun berdasarkan dimensi-dimensi konsep diri oleh Fitss yaitu: 1) Diri fisik, yaitu menggambarkan bagaimana seseorang menilai kondisi kesehatan, badan dan penampilan fisiknya, 2) Diri Etik dan Moral, yaitu menggambarkan bagaimana individu menilai mengenai nilai-nilai moral yang dianutnya: sifat-sifat baik dan jelek serta hubungannya dengan tuhannya, 3) Diri Sosial, yaitu menandakan sejauh mana seseorang merasakan bahwa dirinya mampu serta berharga dalam interaksi sosialnya bersama orang lain, 4) Diri pribadi, yaitu menggambarkan penilaian individu terhadap kemampuan dirinya sendiri dan dengan interaksi sosialnya, 5) Diri keluarga adalah dimensi yang menggambarkan perasaan berarti dan berharga dalam kepastiannya sebagai anggota di dalam sebuah keluarga. Skala konsep diri disusun menjadi 75 aitem uji coba dan dihasilkan 40 aitem valid yang digunakan dalam penelitian ini. Sedangkan skala self control disusun berdasarkan dimensi-dimensi self control oleh Averill yaitu, 1) Kemampuan mengontrol perilaku yaitu kemampuan yang dimiliki individu dalam mengendalikan stimulus dan respon yang dimilikinya agar tidak terjadi ledakan emosi dan frustasi, 2) Kontrol kognitif adalah kemampuan individu dalam pengelolaan informasi yang didapatkannya melalui penginterpretasian, penilaian dan penggabungan suatu kejadian dalam kerangka kognitif sebagai bentuk adaptasi psikologis, (3) Kemampuan Mengontrol Keputusan adalah kemampuan individu dalam menentukan suatu tindakan tertentu yang didasarkan pada sesuatu yang diyakininya dan disetujuinya. Skala self control disusun menjadi 43 aitem uji coba dan dihasilkan 22 aitem valid yang digunakan dalam penelitian ini.

Metode statistik yang digunakan yaitu tekhnik analisis regresi. Selanjutnya adalah analisis korelasi parsial untuk menguji hubungan masing-masing indepent variabel. 


\section{Hasil Penelitian}

Pada tabel 1 deskripsi statistik maka akan menggambarkan data sebagai berikut. Analisis pada variabel konsep diri dihasilkan $\mathrm{N}$ sebesar 120, dari 120 responden nilai terendah (minimum) 87 dan nilai tertinggi (maximum) adalah 141 dengan nilai rata-rata adalah 113.4917, sedangkan standart deviasi sebesar 13.51065. Selanjutnya pada variabel self control dihasilkan N sebesar 120, dari 120 responden nilai terendah (minimum) 25 dan nilai tertinggi (maximum) adalah 81 dengan nilai rata-rata 56.4833, sedangkan standart deviasi sebesar 10.03438. pada variabel kebermaknaan hidup dihasilkan N sebesar 120, dari 120 responden nilai terendah (minimum) 51 dan nilai tertinggi (maximum) adalah 132, nilai rata-rata 101.2667 dengan standart deviasi 15.69335.

Tabel 1. Deskripsi Statistik

\begin{tabular}{lccccc}
\hline & Jumlah & Terendah & Tertinggi & Rata-rata & Standart Deviasi \\
\hline Konsep Diri & 120 & 87 & 141 & 113.4917 & 13.51065 \\
Selr Control & 120 & 25 & 81 & 56.4833 & 10.03438 \\
Kebermaknaan & 120 & 51 & 132 & 101.2667 & 15.69335 \\
Hidup & 120 & & & & \\
Jumlah Valid & & & & \\
\hline
\end{tabular}

Adapun hasil uji reliabilitas skala konsep diri, self control dan kebermaknaan hidup adalah sebagai berikut:

Tabel 2. Uji Reliabilitas

\begin{tabular}{lcc}
\hline \multicolumn{1}{c}{ Variabel } & Cronbach's Alpha & Jumlah Aitem \\
\hline Konsep Diri & 0,822 & 40 \\
Self Control & 0,827 & 22 \\
Kebermaknaan Hidup & 0,913 & 35 \\
\hline
\end{tabular}

Menurut Azwar (2013) Reliabilitas skala pengukuran dianggap memuaskan apabila koefisienn reliabilitasnya minimun 0,900. Apabila tidak dapat memenuhi standar 0.900 kiranya dapat dipertimbangkan argumen Kaplan dan Saccuze bahwa koefisienn reliiabilitas 0,700 dapat digunakan untuk penelitian, Penelitian ini ditetapkan besaran minimum koefisie reliabilitas alat ukur sebesar 0,700, yang berarti perbedaan (variiasi) yang tampak pada skor skala tersebut mampu mencerminkan $70 \%$ dari variasi yang terjadi pada skor yang tampak disebabkan oleh variasi kesalahan pengukuran (Azwar, 2013).

Pada tabel Uji Reliabilitas diketahui nilai Alpha Cronbach pada variabel Konsep Diri sebesar 0,822 > 0,700, maka aitem yang digunakan penelitian ini reliabel. Sedangkan pada variabel self control diperoleh nilai alpha cronbach sebesar 0,827 $>0,700$, maka variabel penelitian ini reliabel. Serta pada variabel Kebermaknaan Hidup diperoleh nilai Alpha Cronbach sebesar 0,913>0,700, maka aitem pada variabel ini dinyatakan reliabel.

Sebelum melakukan analisis data, terlebih dahulu dilakukan uji prasyarat analisis. Hal tersebut dibutuhkan untuk mengetahui apakah analisis data untuk pengujian hipotesis dapat dilanjutkan atau tidak. uji prasyarat meliputi uji normalitas dan uji linieritas. Uji normalitas data dilakukan untuk mengetahui apakah data yang diperoleh dari masing-masing variabel penelitian bervariasi atau berdistribusi secara normal atau tidak. berdasarkan kaidah apabila signifikansi $>0,05$ dapat disimpulkan data berdistribusi normal. Sebaliknya, jika signifikansi $<0,05$ maka disimpulkan data tidak normal. Hasil normalitas dari ketiga variabel dapat dilihat pada tabel sebagai berikut: 


\begin{tabular}{llr}
\hline $\mathrm{N}$ & & 120 \\
\hline Normal Parameters & & \\
& Mean & 56.4833 \\
& Std. & 10.03438 \\
& Deviation & \\
Most Extreme & Absolute & .068 \\
Differences & Positive & .068 \\
& Negative & -.045 \\
Kolmogorov-Smirnov Z & & .745 \\
Asymp. Sig. (2-tailed) & & .636 \\
\hline
\end{tabular}

Uji normalitas menggunakan pendekatan Kolmogorov-Smirnov untuk mengetahui apakah sebaran normal ataukah tidak. kaidah yang digunakan ialah jika $\mathrm{P}>0,05$ maka sebaran dapat dikatakan normal dan sebaliknya jika $\mathrm{P}<0,05$, maka sebaran dapat dikatakan tidak normal. Dari hasil didapat $\mathrm{P}$ $=0,636>0,05$, maka dapat dikatakan sebaran memenuhi asumsi normalitas.

Uji linieritas dilakukan untuk mengetahui apakah variabel konsep diri dengan kebermaknaan hidup mempunyai hubungan linier atau tidak, dan untuk mengetahui apakah variabel self control dengan kebermaknaan hidup mempunyai hubungan linier atau tidak. Kaidah yang digunakan untuk megetahui linieritas hubungan antara variabel bebas dan variabel terikat adalah jika $\mathrm{P}>0,05$ maka hubungannya tidak linier, sebaliknya jika $\mathrm{p}<0,05$ maka hubungannya linier.

Tabel 4. hasil Uji Linieritas Konsep Diri dengan Kebermaknaan Hidup

\begin{tabular}{lcccc}
\hline \multicolumn{1}{c}{ Variabel } & $\mathrm{F}$ & Signifikan & Keterangan & Kesimpulan \\
\hline $\begin{array}{l}\text { Konsep Diri dengan } \\
\text { Kebermaknaan Hidup }\end{array}$ & 1.131 & .316 & Sig> 0.05 & Tidak Linier \\
\hline
\end{tabular}

Jika nilai signifikan pada Deviation From Linearity lebih kecil dari $0.05(\mathrm{p}<0.05)$ berarti hubungan antara variabel independent dengan variabel dependent adalah linier. Berdasarkan uji linieritas hubungan dengan tekhnik analisis regresi diperoleh nilai $\mathrm{F}$ hitung sebesar $1.131(\mathrm{p}=0.316)$. hal ini menunjukkan tidak adanya hubungan yang linier antara variabel konsep diri dengan kebermaknaan hidup.

Tabel 5. Hasil Uji Linieritas Self Control dengan Kebermaknaan Hidup

\begin{tabular}{lcccc}
\hline \multicolumn{1}{c}{ Variabel } & F & Signifikan & Keterangan & Kesimpulan \\
\hline $\begin{array}{l}\text { Self Control dengan } \\
\text { Kebermaknaan Hidup }\end{array}$ & 1.290 & 0.176 & Sig $>0.005$ & Tidak Linier \\
\hline
\end{tabular}

Jika nilai signifikan pada Deviation From Linearity lebih kecil dari $0.05(\mathrm{p}<0.05)$ berarti hubungan antara variabel independent dengan variabel dependent adalah linier. Dari hasil uji linieritas variabel Self Control dengan Kebermaknaan Hidup diperoleh F beda sebesar 1.290 ( $\mathrm{p}=0.176$ ) hal ini menunjukan tidak adanya hubungan yang linier antara variabel Self Control dengan Kebermaknaan Hidup.

Pengujian hipotesis dalam penelitian ini menggunakan metode regresi linier untuk menguji hubungan antara variabel X1 (Konsep Diri) dan X2 (Self Control) dengan variebel Y, yaitu Kebermaknaan Hidup. Adapun hasil uji hipotesis menggunakan program SPSS, sebagai berikut:

Tabel 6. Hasil Analisis Uji F Annova

\begin{tabular}{lccccc}
\hline \multicolumn{1}{c}{ Model } & Sum of Squares & $\mathrm{df}$ & Mean Square & $\mathrm{F}$ & Sig. \\
\hline Regression & 16310.364 & 2 & 8155.182 & 73.413 & $.000^{\mathrm{b}}$ \\
Residual & 12997.102 & 117 & 111.086 & & \\
Total & 29307.467 & 119 & & & \\
\hline
\end{tabular}


Hipotesis pertama berbunyi bahwa secara bersama-sama konsep diri dan self control mempunyai hubungan yang positif dengan kebermaknaan hidup, di mana semakin tinggi konsep diri dan self control pada individu maka semakin tinggi pula kebermaknaan hidup pada individu tersebut. Hasil olah data penelitian yang dilakukan secara simultan dalam uji hipotesis didapatkan nilai $\mathrm{F}$ hitung sebesar $=$ 73.413 sedangkan nilai $\mathrm{P}=.000$ sehinga $\mathrm{F}$ hitung $>$ nilai $\mathrm{P}$, dengan $\mathrm{p}=0.000(\mathrm{p}<0.01)$, berarti hal ini menunjukan ada hubungan yang signifikan antara konsep diri dan self control secara bersama-sama mempengaruhi kebermaknaan hidup, dengan kata lain ada hubungan positif secara parsial antara konsep diri dan self control dengan kebermaknaan hidup. Dari hasil tersebut maka hipotesis pertama yang berbunyi ada hubungan positif anatara konsep diri dan self control dengan kebermaknaan hidup diterima.

Dari hasil analisis olah data SPSS menunjukan bahwa konsep diri dan self control secara bersama-sama memberikan sumbangan efektif (SE) terhadap kebermaknaan hidup sebesar $55.7 \%$ dengan nilai $\mathrm{R}$ Square $=.746$, artinya sisanya sebesar $44.3 \%$ dipengaruhi oleh variabel lain yang tidak dimasukan dalam penelitian ini. Hal ini menggambarkan bahwa peran kedua variabel bebas terhadap variabel tergantung cukup besar.

Tabel 7. Hasil Analisis Uji t-Cooefficient

\begin{tabular}{lccccc}
\hline \multicolumn{7}{c}{ Unstandardized Coefficients } & $\begin{array}{c}\text { Standardized } \\
\text { Coefficients }\end{array}$ & & \\
Model & $\mathrm{B}$ & Std. Error & Beta & T & Sig. \\
\hline (Constant) & 7.883 & 8.191 & & .962 & .338 \\
X1 & .540 & .091 & .465 & 5.945 & .000 \\
X2 & .567 & .122 & .363 & 4.636 & .000 \\
\hline
\end{tabular}

Hipotesis Kedua berbunyi bahwa konsep diri memiliki hubungan positif dengan kebermaknaan hidup, dimana semakin tinggi konsep diri pada individu maka semakin tinggi pula kebermaknaan hidupnya. Dari hasil olah data penelitian yang dilakukan dalam uji hipotesis didapatkan $t$ hitung variabel konsep diri dengan kebermaknaan hidup sebesar $=5.945$ sedangkan nilai $\mathrm{P}$ sebesar 0.000 sehinga t hitung $>$ dengan $\mathrm{p}=0.000(\mathrm{p}<0.01)$, berarti menunjukan ada hubungan yang sangat signifikan antara konsep diri dengan kebermaknaan hidup. Semakin tinggi konsep diri individu, maka semakin tinggi pula kebermaknaan hidupnya. Dengan kata lain ada hubungan yang positif secara parsial antara konsep diri dengan kebermaknaan hidup. Dari hasil tersebut maka hipotesi pertama yang berbunyi ada hubungan positif antara konsep diri dengan kebermaknaan hidup diterima.

Hipotesis Ketiga berbunyi bahwa self control memiliki hubungan yang positif dengan kebermaknaan hidup, dimana semakin tinggi self control pada individu maka semakin tinggi pula kebermaknaan hidupnya. Dari hasil olah data penelitian yang dilakukan dalam uji hipotesis didapatkan t hitung variabel self control dengan kebermaknaan hidup sebesar $=4.636$ sedangkan nilai $\mathrm{P}$ tabel sebesar 0.000 sehinga t hitung $>$ dengan $\mathrm{p}=0.000(\mathrm{p}<0.01)$, berarti menunjukan ada hubungan yang positif antara self control dengan kebermaknaan hidup. Dengan kata lain ada hubungan secara parsial antara self control dengan kebermaknaan hidup. Dari hasil tersebut maka hipotesis kedua yang berbunyi ada hubungan positif anatara self control dengan kebermaknaan hidup diterima.

Jumlah sampel yang berjumlah 120 siswa yang dikategorikan menjadi tiga kategori pada masingmasing variabel. Berdasarjan hasil uji statistik deskriptif variabel kebermaknaan hidup didapatkan terdapat 21 siswa dalam kategori kebermaknaan hidup baik, 83 siswa dalam kategori cukup dan 16 siswa dalam kategori kebermaknaan hidup yang rendah. Hasil tersebut dapat dilihat pada tabel berikut:

Tabel 8. Nilai Responden pada Variabel Kebermaknaan Hidup

\begin{tabular}{ccc}
\hline Kategori & Frekuensi & Persen \\
\hline Baik & 21 & $17,5 \%$ \\
Cukup & 83 & $69,2 \%$ \\
Kurang & 16 & $13,3 \%$ \\
Total & 120 & $100 \%$ \\
\hline
\end{tabular}


Tabel di atas menunjukkan bahwa pada umumnya tingkat kebermaknaan hidup siswa MA Mathali'ul Anwar Simo Kabupaten Lamongan adalah sedang dengan presentase sebesar 69,2\%. Besaran tersebut menunjukkan bahwa kebanyakan siswa yang menempuh pendidikan di MA Mathali'ul Anwar memiliki penghayatan hidup yang bermakna dalam taraf sedang.

Berdasarjan hasil uji statistik deskriptif variabel Konsep Diri didapatkan terdapat 18 siswa dalam kategori Konsep Diri baik, 83 siswa dalam kategori cukup dan 19 siswa dalam kategori konsep diri yang kurang. Hasil tersebut dapat dilihat pada tabel berikut:

Tabel 9. Nilai Responden pada Variabel Konsep Diri

\begin{tabular}{ccc}
\hline Kategori & Frekuensi & Persen \\
\hline Baik & 18 & $15 \%$ \\
Cukup & 83 & $69,2 \%$ \\
Kurang & 19 & $15,8 \%$ \\
Total & 120 & $100 \%$
\end{tabular}

Pada Tabel di atas menunjukkan bahwa konsep diri siswa di Mathali'ul Anwar Simo-Lamongan bertumpu pada kategori sedang sebesar $69 \%$, artinya rata-rata siswa di madrasah tersebut memiliki konsep diri yang cukup.

Berdasarjan hasil uji statistik deskriptif variabel Self Control didapatkan terdapat 21 siswa dalam kategori Self Control baik, 38 siswa dalam kategori cukup dan 61 siswa dalam kategori self control yang kurang. Hasil tersebut dapat dilihat pada tabel berikut:

Tabel 10. Nilai Responden pada Variabel Self Control

\begin{tabular}{lcc}
\hline Kategori & Frekuensi & Persen \\
\hline Baik & 21 & $17,5 \%$ \\
Cukup & 38 & $31,7 \%$ \\
Kurang & 61 & $50,8 \%$ \\
Total & 120 & $100 \%$ \\
\hline
\end{tabular}

Dari Tabel tersebut diketahui bahwa self control siswa di Mathali'ul Anwar Simo-Lamongan bertumpu pada kategori kurang yaitu sebesar $69 \%$, artinya rata-rata siswa di madrasah tersebut memiliki self control yang kurang.

\section{Pembahasan}

Hasil penelitian menunjukkan hipotesis pertama yang menyatakan ada hubungan antara konsep diri dan self control dengan kebermaknaan hidup diterima, ini berarti ada korelasi positif antara konsep diri dan self control dengan kebermaknaan hidup. Hal ini berarti semakin tinggi konsep diri dan self control individu, maka semakin tinggi pula kebermaknaan hidupnya. Maka, penelitian ini memperkuat penelitian sebelumnya yang menjelaskan bahwa faktor yang berkaitan dengan kebermaknaan hidup adalah konsep diri (Lubis dan Maslihah, 2012 ; Mazaya dan Supradewi, 2011).

Menurut Mazaya dan Supradewi (2011) individu pada dasarnya menginginkan keberhasilan di dalam kehidupannya. Individu dengan konsep diri yang kurang senantiasa memandang hidupnya tidak beruntung, dan tidak sempurna sehingga melemahkan daya juang, semangat untuk mencapai apa yang dicita-citakan. Demikian pada akhirnya menimbukan kehilangan kebermaknaan hidup. Bastaman (2004) menerangkan bahwa individu pada dasarnya menginginkan kebermaknaan hidup, ketika sesuatu yang dianggap penting dan bernilai tercapai, maka ia akan merasakan kebermaknaan hidupnya dan digantikan dengan makna hidup baru yang harus menantang untuk diupayakan. hal ini diasumsikan bagi siswa yang mengenal dan dapat menilai dirinya apa adanya sehingga kehidupannya tidak dirudung oleh pikiran yang negatif, ia akan berusaha secara maksimal mencapai apa yang dicita-citakannya dan itu adalah makna hidupnya. Makna hidup yang berhasil direalisasikan akan mendatangkan kebermaknaan hidup bagi siswa tersebut. Semakin baik siswa mengenal dirinya, menghayati segala kelebihan dan kelemahannya, maka semakin baik pula kebermaknaan hidupnya. ketika para siswa menghadapi suatu kondisi yang menantang semisal ujian, maka ia belajar jauh-jauh hari, ia tidak belajar dengan sekali waktu. Perilaku siswa tersebut mencerminkan bahwa dirinya sadar akan segala 
keterbatasan dan kemampuannya, sehingga ia perlu berusaha sebagai upaya menjalani proses menuju keberhasilan.

Siswa dengan konsep diri yang baik senantiasa berusaha melaksanakan tugas hidupnya sebagai siswa. Kesadaran bahwa dirinya dapat melaksanakan dengan kenyataan dirinya mampu mendorongnya untuk melaksanakan tugas tersebut. Tugas hidup siswa adalah dalam perannya sebagai siswa di sekolah, sebagai anak di dalam keluarganya dan sebagai anggota masyarakat, serta sebagai teman. Kesemua tugas hidup dalam perannya yang bermacam-macam tersebut diupayakan oleh siswa dengan konsep diri yang baik. Hal ini dapat disimpulkan bahwa dengan konsep diri yang baik siswa akan berperilaku yang baik pula (Kurniawan, 2009).

Menurut Rakhmat (2012) konsep diri ikut menentukan bagaimana individu berpikir. Konsep diri yang negatif akan menjadikan individu berpikir dengan cara negatif semisal ia berpikir bahwa dirinya tidak mampu, padahal dirinya mampu. Kondisi demikian tentu tidak dapat menghantarkan individu dalam implementasi nilai-nilai penghayatan, ia tak berusaha mencapai makna hidup yang menuntut untuk dicapai. Oleh sebab itu, kemampuan berpikir positif sebagai wujud dari konsep diri yang baik dibutuhkan dalam rangka meningkatkan kebermaknaan hidup. Bila makna hidup tidak bersifat menantang, maka kebermaknaan hidup yang dinyatakan atau dirasakan oleh individu hanyalah merupakan gambaran-gambaran deskriptif semata (Koeswara, 1992). Bagi siswa, makna hidup yang menantang itu adalah apa yang menurutnya penting dan berguna dengan tidak mengindahkan perannya dalam kehidupan sebagai pelaksanaan dari tugas hidupnya: sebagai anggota keluarga, sebagai siswa, sebagai teman dan sebagai anggota masyarakat.

Konsep diri dan self control bersama-sama dapat meningkatkan kebermaknaan hidup. Perpaduan konsep diri dan self control sangatlah penting dalam rangka meningkatkan kebermaknaan hidup pada siswa. Self control menurut Goldfired dan Merbaum (dalam Aviyah dan Farid, 2014) dipahami sebagai kemampuan untuk menyusun, membimbing, mengatur dan mengarahkan perilaku yang dapat membawa individu ke arah konsekuensi positif. Siswa dengan self control yang baik dapat menyusun suatu perencanaan dan pengendalian guna mencapai suatu konsekuensi akhir yang positif. Di dalam mengendalikan tersebut dibutuhkan suatu kemampuan mengontrol perilaku, kognitif dan keputusan. Pencapaian terhadap suatu koensekuensi positif merupakan pencapaian terhadap apa yang diyakininya sebagai hal penting, berguna dan bernilai khusus yang berarti merupakan pencapaian ke arah makna hidup. Pencapaian terhadap makna hidup akan mendatangkan kebermaknaan hidup. Mengingat bahwa makna hidup merupakan sesuatu yang penting dan menantang dan menuntut individu (Koeswara, 1992).

Siswa dengan self control yang baik mampu mengatur dirinya dalam waktu demi menuju suatu hasil tindakan yang positif. Hasil tindakan yang positif bagi siswa sebenarnya adalah makna hidupnya, karena menurutnya hasil tindakan positif tersebut merupakan sesuatu yang didambakan, dianggap penting dan bernilai bagi individu tersebut. Ketika ia mengupayakan hal tersebut tercapai, maka sebenarnya ia mengupayakan nilai-nilai kreatif yang merupakan sumber kebermaknaan hidup. Pada nilai ini individu dituntut untuk memberikan kepada kehidupan, yaitu bagaimana individu mengisi penuh lingkaran aktivitasnya di dalam usaha tersebut (Koeswara, 1992). Hal tersebut di atas mendukung penelitian sebelumnya bahwa kebermaknaan hidup ditentukan oleh nilai-nilai kreatif sebagai bagian darinya (Lubis dan Maslihah, 2012).

Siswa yang berada di MA Mathali'ul Anwar memiliki presentase kebermaknaan hidup dan konsep diri yang bertumpu pada kategori cukup atau sedang. Sedangkan pada variabel self control menunjukkan pada umumnya siswa tersebut memiliki self control yang kurang atau rendah. Dengan demikian, maka kebermaknaan hidup siswa perlu ditingkatkan dengan meningkatkan konsep diri dan self controlnya.

Hasil analisis data menunjukkan hipotesis kedua yang menyatakan ada hubungan antara konsep diri dengan kebermaknaan hidup diterima, ini berarti ada korelasi positif antara konsep diri dengan kebermaknaan hidup. Hasil penelitian ini menunjukkan semakin tinggi konsep diri individu, maka semakin tinggi pula kebermaknaan hidupnya. hasil penelitian ini mendukung dari penelitian yang dilakukan sebelumnya oleh Mazaya dan Supradewi (2011). Penelitian tersebut sebenarnya menunjukkan bahwa konsep diri memiliki peran penting dalam mewujudkan kebermaknaan hidup pada remaja. Kebermaknaan hidup menurutnya dipengaruhi oleh kualitas insani termasuk di dalamnya kesadaran diri. Di dalam kesadaran ini individu membawa diri kepada usaha pemenuhan akan makna hidupnya yang bersifat menantang, yaitu dengan membawa segala kemampuan dan keunikan diri yang 
dimilikinya. Untuk dapat membawa diri dengan segala keunikannya dalam usaha mencapai makna hidup diperlukan pengenalan diri lebih baik yaitu dengan mengenal kelebihan dan kekurangan diri sendiri.

Menurut Frankl (dalam Koeswara, 1992) pencapaian kebermaknaan hidup bagi siswa sangat diperlukan meskipun bersifat unik dan temporal artinya proses pencapaian makna hidup tidak abadi dan silih berganti. Ketika satu makna hidup tercapai, maka akan muncul makna hidup baru yang menuntutnya untuk dicapai (Bastaman, 2004).

Kebermaknaan hidup pada siswa dapat digambarkan sebagai kualitas penghayatan dirinya terhadap kehidupannya yang dapat mengarahkan dirinya kepada suatu tindakan yang positif dan bermanfaat, Koeswara (1992). Meskipun demikian, makna hidup antara satu individu tak sama dengan individu yang lain karena sifatnya yang bersifat unik, Bastaman (2004). Siswa dengan kebermaknaan hidup dapat didiskripsikan dengan individu yang memiliki arah dalam hidupnya, memiliki minat terhadap sesuatunya yang bermanfaat, memiliki keinginan yang kuat untuk memberikan sesuatu kepada hidup-berprestasi, membantu orang lain dan melakukan tindakan-tindakan yang positif. Mazaya dan Supradewi (2012) menggambarkan individu dengan kebermaknaan hidup adalah mereka secara sadar berusaha meningkatkan cara berpikir, bertindak positif dan mengembangkan potensi diri untuk meningkatkan kualitas hidup yang lebih baik dan mencapai cita-cita yang diimpikan.

Konsep diri terkait bagaimana individu mengenal dan menilai dirinya sendiri dari segala aspeknya. Dengan mengenal diri dapat membantu bagi perkembangan potensi-potensi yang ada d dalam diri dan mengurangi segi-segi yang negatif dan menyadari apa yang sebenarnya penting untuk dicapai ke depannya. Dengan kesadaran tersebut individu berusaha untuk mencapai makna hidupnya tersebut yang diyakini sebagai hal yang penting (Mazaya dan Supradewi, 2012).

Di dalam usaha pencapaian makna hidup yang berbeda juga dibutuhkan keunikan diri, artinya individu membawa segala kelebihan dan kekurangan dirinya dalam usaha menjawab tantangan makna hidup. Karena sifatnya yang objektif dan menantang itulah mengapa pada nantinya makna hidup mengandung tujuan hidup. Makna hidup yang bersifat menuntut menjadikan makna hidup tidak sebagai ungkapan keberadaan saja (Koeswara, 1992).

Di dalam mengupayakan kebermaknaan hidup diperlukan upaya impelementasi nilai-nilai kreatif, nilai-nilai penghayatan dan nilai-nilai bersikap. Nilai-nilai kreatif (creative values) menurut Frankl, makna hidup tidak dicapai hanya dengan usaha intelektualitasnya, namun juga dengan nilainilai kreatif. Dalam nilai ini, individu dituntut untuk memberikan sesuatu kepada kehidupan yang terintegrasi dalam suatu pekerjaan dengan pendekatan kreatif dan berlandaskan pada totalitas keberadaan dirinya. Bagaimana menjalani suatu pekerjaan atau aktivitas adalah fokus bagi nilai kreatif dibanding dengan pekerjaan itu sendiri. Yaitu, bagaimana individu bekerja dan mengisi penuh lingkaran pada aktivitasnya (Koeswara, 1992). Dalam usaha mengisi penuh lingkaran aktivitas individu diperlukan pengenalan diri yang utuh sehingga dapat mengupayakan dengan baik.

Nilai-nilai kreatif ini tercermin dalam kegiatan semisal melaksanakan aktivitas yang merupakan kewajibab sebagai siswa di sekolah maupun di dalam keluarga dengan cara dilakukan dengan sebaik-baiknya. Individu dengan konsep diri yang kurang (negatif) menjadi orang yang cenderung berperilaku negatif, pengharapan tidak realistis dan harga diri rendah serta pesimistik (Kurniawan, 2009). Bila demikian keadaannya, maka usaha untuk mengimplementasikan nilai-nilai kreatif yang membutuhkan pelaksanaan dengan cara sebaik-baiknya menjadi tidak maksimal dengan demikian konsep diri ikut mempengaruhi sejauh mana kebermaknaan hidup seseorang. Apalagi nilainilai kreatif ini juga diimplementasikan dalam hubungan individu dengan sesama, padahal individu dengan konsep diri negatif cenderung menghindari kontak dengan orang lain.

Nilai-nilai penghayatan (experiential values) Nilai-nilai penghayatan berkebalikan dengan nilai-nilai kreatif. Hal ini dijelaskan oleh Frankl bahwa nilai-nilai penghayatan adalah nilai yang direalisasikan dengan sikap menerima dari atau menyerahkan diri kepada kehidupan (Koeswara, 1992). Nilai-nilai penghayatan dapat dirasakan dalam pertemuan dengan kebenaran, keindahan, keagamaan, kebajikan dan kebijaksanaan. Penghayatan dan keyakinan terhadap hal tersebut menyebabkan individu merasakan keberartian di dalam hidupnya (Bastaman, 2004). Nilai ini tercermin ketika siswa melaksanakan kewajibannya sebagai siswa, dan anggota keluarga di rumahnya atau di pesantren. Selain itu dengan membantu orang lain. Konsep diri yang positif menjadikan individu berperilaku positif, sehingga ia merasakan pertemuannya dengan kebajikan dan kebenaran. Hal demikian tentu memberikan suatu kebermaknaan hidup baginya sebagai implementasi dari nilai penghayatan tersebut. 
Sebaliknya, individu dengan konsep diri negatif yang cenderung berperilaku negatif tidak akan bersentuhan dengan nilai kebaikan dan kebajikan ini, sehingga hal tersebut merugikan orang lain dan dirinya sendiri. Bila pun demikian kenyataannya, maka kebermaknaan hidup sulit dicapai.

Nilai-nilai bersikap (attitudinal values) Nilai ini tergambarkan dalam bentuk penerimaan diri dengan penuh ketabahan, keberanian dan ketabahan akan segala bentuk penderitaan yang tak terelakan: kesakitan, kegagalan setelah ikhtiar yang maksimal, dan kematian. Dalam hal ini, individu tidak mengubah keadaan, namun bagaimana menyikapi (attitude) kehidupan tersebut. Individu dengan konsep diri negatif cenderung bersikap pesimistik, peka terhadap kritikan dan pesimistik terhadap tantangan dan keadaan. Hal demikian akan menyebabkan individu kesulitan dalam mengimplementasi niali-nilai bersikap sebagai wujud dari sumber kebermaknaan hidup.

Hasil analisis data menunjukkan hipotesis ketiga yang menyatakan ada hubungan antara self control dengan kebermaknaan hidup diterima, ini berarti ada korelasi positif antara control diri dengan kebermaknaan hidup. Hasil penelitian ini menunjukkan semakin tinggi self control individu, maka semakin tinggi pula kebermaknaan hidupnya. penelitian ini mendukung hasil penelitian Arwansyah dan Gazi.

Siswa yamg hidupnya bermakna memiliki tujuan yang jelas dan mengisi setiap sendi-sendi kehidupannya dengan afeksi yang 'hangat'. Makna hidup yang bersifat khas pada masing-masing individu didapatkan dari adanya variasi perbedaan individual; kehidupan tiap individu dan mata pencaharian. Kekhasan tersebut tergantung dari kemampuan individu dalam menghadapi kompleksitas, tantangan dan perubahan dalam kehidupan sehari-hari dan pekerjaan. Perbedaan pemaknaan satu individu dengan yang lainnya mengisyaratkan sejauh mana individu menemukan pemenuhan hidup dan mencapai potensi tertinggi mereka (Setyarini dan Atamimi, 2011).

Siswa dengan self control yang baik dicirikan dengan kemampuan mengontrol perilaku yang baik, kontrol kognitif dan keputusan yang baik. Kemampuan ini meliputi kemampuan seseorang dalam mengontrol stimulus dan respon yang dimiliki, sehingga tidak terjadi ledakan emosi dan frustasi (Megalia, 2016). Aspek ini memiliki dua indikator (Mukhtar, dkk., 2016), yaitu: Mengatur pelaksanaan (regulated administration) yaitu kemampuan individu untuk menentukan siapa yang mengendalikan situasi atau keadaan. Pengendalian tersebut dapat bersumber dari dirinya sendiri dan apabila individu tidak mampu maka akan menggunakan sumber eksternal. Kemampuan memodifikasi stimulus (stimulus modifiability).Merupakan kemampuan untuk mengetahui bagaimana dan kapan suatu stimulus yang tidak dikehendaki dihadapi (Wulaningsih \& Hartini, 2015). Kemampuan kontrol perilaku yang baik pada siswa ini dengan kemampuan mengendalikan stimulus, yaitu dengan memilih respon sehingga tidak terjadi ledakan emosi atau frustasi. Kemampuan kontrol ini dibutuhkan dalam mengupayakan dalam implementasi nilai kreatif sebagai sumber makna hidup. Di dalam nilai kreatif individu dituntut untuk memberikan sesuatu kepada kehidupan yang terintegrasi dalam suatu pekerjaan dengan pendekatan kreatif dan berlandaskan pada totalitas keberadaan dirinya. Bagaimana menjalani suatu pekerjaan atau aktivitas adalah fokus bagi nilai kreatif dibanding dengan pekerjaan itu sendiri. Yaitu, bagaimana individu bekerja dan mengisi penuh lingkaran pada aktivitasnya (Koeswara, 1992). Di dalam upaya mengisi penuh lingkaran pada aktivitas individu diperlukan kemampuan kontrol diri yang baik sehingga tercapainya nilai tersebut menyebabkan pencapaian daripada kebermaknaan hidup individu.

\section{Kesimpulan}

Hasil analisis dari penelitian ini dapat disimpulkan bahwa konsep diri dan self control secara simultan dan sangat signifikan berkorelasi dengan kebermaknaan hidup. Selain itu, terdapat hubungan antara variabel konsep diri dengan kebermaknaan hidup. Begitu pula dengan variabel self control dengan kebermaknaan hidup. Adapun konsep diri berkontribusi meningkatkan kebermaknaan hidup dengan nilai sebesar $47,5 \%$, sedangkan self control berkontribusi sebesar $42,3 \%$ untuk meningkatkan kebermaknaan hidup. Sedangkan sisanya ditentukan oleh faktor-faktor lain.

\section{Daftar Pustaka}

Alfian, dalam http://tribunnews.com/amp/regional/2016/08/10/oknum-orangtua-penganiaya-guru-smk-2makasar-hampir-dikeroyok-siswa?espv=1, diakses 05, Maret 2018. 
Aviyah, Farid. (2014). Religiusitas, Kontrol Diri dan Kenakalan Remaja. Persona, Jurnal Psikologi Indonesia. 3 (02). 126-129.

Azwar, S. (2013). Metode Penelitian. Edisi 2. Pustaka Pelajar. Yogyakarta.

Bastaman, H.D. (2004). Logoterapi Psikologi untuk Menemukan Makna Hidup dan Meraih Hidup Bermakna. PT Raja Grafindo Persada. Jakarta.

Edzan Rahardjo, dalam http://detik.com/news/berita/d-338348/kasus-tawuran-pelajar-di-yogyakartameningkat-di-tahun-2016, diakses 05, Maret 2018.

Fitang Budhi Adhitia, dalam http://www.idntimes.com/news/indonesia/amp/fitang-adhitia/sepanjangtahun-2017-bnn-ungkap-46537-kasus-narkoba?espv=1, diakses 05, Maret 2018.

Fitts, W. H. (1965). Manual For Tennessee self concept Scale. Western Psychological Source. Los Angeles.

Frankl, Victor E. Man's Search for Meaning: An Introduction to Logoteraphy. (2003). Logoterapi: Terapi Psikologi Melalui Pemaknaan Eksistensi. M. Murtadio (terj). Kreasi Wacana. Yogyakarta.

Gita Amanda, dalam http://www.republika.co.id/amp_version/oymn2n423/espv=1, diakses 05, Maret 2018.

Haryani, Indah dan J. Herwanto. (2015). Hubungan Konformitas dan Kontrol Diri dengan Perilaku Konsumtif Terhadap Produk Kosmetik pada Mahasiswi. Jurnal Psikologi 11. 1. 5-11.

Jerome Wirawan, dalam http://www.bbc.com/indonesia/amp/indonesia-42949180?espv=1, diakses 05, Maret 2018.

Khaairunnisa, A. (2013). Hubungan Religiusitas dan Kontrol Diri dengan Perilaku Seksual Pranikah Remaja di MAN 1 Samarinda. Ejurnal psikologi. 1(2). 220-229.

Koeswara, E. (1992). Logoterapi Psikologi Viktor Frankl. Penerbit Kanisius. Jogjakarta.

Kurniawan, Teguh. (2009). Hubungan Antara Interaksi Teman Sebaya dan Konsep Diri dengan Intensi Perilaku Seks Pranikah Pada Remaja. Skripsi. Universitas Muhammadiyah Surakarta.

Kurniawan, Wahyu dan Rahma Widyana. (2014). Pengaruh Pelatihan Dzikir Terhadap Peningkatan Kebermaknaan Hidup Pada Mahasiswa. Jurnal Intervensi Psikologi. 6. 67-87.

Lubis, Siska Marliana \& Sri Maslihah. (2012). Analisis Sumber-Sumber Kebermaknaan Hidup Narapidana yang Menajalani Hukuman Seumur Hidup. Jurnal Psikologi Undip. 11 (1). 28-39.

Lukman, Muhammad. (2000). Kemandirian Anak Asuh di Panti Asuhan Yatim Islam Ditinjau dari Konsep Diri dan Kompetensi Interpersonal. Psikologika. 10 (5). 57-74.

Mazaya, Kharisma Nail \& Ratna Supradewi. (2011). Konsep Diri dan Kebermaknaan Hidup pada Remaja di Panti Asuhan. Proyeksi. 6 (2): 103-112.

Monks, F. J. (2012). Psikologi Perkembangan Pengantar dalam Berbagai Bagiannya. Gajahmada University Press. Yogyakarta.

Rakhmat, Jalaluddin. (2012). Psikologi Komunikasi. PT. Remaja Rosdakarya Offset. Bandung.

Setyarini, Riris dan Nuryati Atamimi (2011). Self-Esteem dan Makna Hidup pada Pensiunan Pegawai Negeri Sipil (PNS). Jurnal Psikologi. Vol. 38: 176-184.

Suryanti, Risa. (2011). Hubungan Antara Locus of Control Internal dan Konsep Diri dengan Kematangan Karir pada Siswa Kelas XI SMK Negeri 2 Surakarta. Skripsi. Universitas Sebelas Maret Surakarta. Diakses dari perpustakaan.uns.ac.id.

RA Dalam http://www.liputan6.com/amp/440140/dalam-setahun-82-pelajar-tewas-akibattawuran?espv=1, diakses 05, Maret 2018.

Wulaningsih, Ratna dan Nurul Hartini. (2015). Hubungan Antara Persepsi Pola Asuh Orang Tua dan Kontrol Diri Remaja Terhadap Perilaku Merokok di Pondok Pesantren. Jurnal Psikologi Klinis dan Kesehatan Mental. 04 (2). 119-126. 